\title{
SOME MORPHOLOGICAL CHARACTERS OF SEXUAL DIMORPHISM ON THE FOOT IN THE CHICK
}

\author{
A. HAMPL \\ Department of Morphology, Physiology and Veterinary Care, Mendel University \\ of Agriculture and Forestry, 61300 Brno \\ Received September 28, 1994 \\ Accepted March 31, 1995
}

\begin{abstract}
H a m p 1 A.: Some Morphological Characters of Sexual Dimorphism on the Foot in the Chick. Acta vet. Brno 1995, 64: 31-33.

Thirty-one male and thirty-one female hatched chicks were examined for possible sexual differences in the foot morphology. In males, the foot (i.e. tarsometatarsus and digits) was significantly $(\mathrm{P}<0.001)$ heavier by $15-16 \%$ than in females, their tarsometatarsus (TMT) was by 4-6\% wider $(\mathrm{P}<0.001)$, and their metatarsal spur (MTS) was by $6 \%$ larger $(\mathrm{P}<0.05)$ than in females. Further, males had a higher number (by $12 \%)$ of scales $(\mathrm{P}<0.05)$ on the pulvinus digitalis distalis of the third digit (PDD III).
\end{abstract}

Avian foot, chick, dimorphism, morphological characters, sexual differences

In our earlier study (H a m p 1 1992) in one-day-old chicks it was found that in cockerels the number of scales on the pulvinus digitalis distalis of the third digit (PDD III) was significantly higher than in pullets. Regarding the fact that in newly hatched chicks the major part of morphological characters of their body is only slightly influenced by various epigenetic factors, we have tried to examine also some other characters indicative of sexual dimorphism using an exactly defined and genetically highly homogeneous material. We decided to study the morphology of feet as they are readily accessible and can therefore be used for the above-mentioned purposes. In mature males, the sexual characters are markedly manisfested in the form of metatarsal spur (MTS), more robust tarsometarsus (TMT) and also more robust digits. L u c a s and S t e t t e $\mathrm{n} \mathrm{h}$ e i m (1972) described the microscopic structure and the postnatal development of MTS.They regarded MTS as a male secondary sex character influenced in its degree of development by the gonadal hormones. P u c h k o v (1979) regarded MTS as a transformed skin scale and found its first embryonal primordium in the form of a very small circular swelling situated on the medial surface of the TMT proximally to the first toe as early as on the 9th day of incubation. This swelling consists of a local mesenchymal condensation covered by a cap of two-layered epidermis. In both sexes, this epidermal cap continued to become thicker during the following days, and a cornification may be observed after the 15th day of incubation. Mesenchyme differentiated in the dermal spur and the underlaying fibrovascular cushion. In cockerels, the postincubation development of MTS is finished by the formation of bony core which later on fuses with the bone of TMT.

\section{Materials and Methods}

Two groups of one-day-old chicks were used in this study, i.e. 31 males and 31 females of the parent breeding stock of Rhode Island White maternal line 02 . The birde were killed, and their sex was verified by gonad inspection after laparotomy. Their feet, cut in the intertarsal joint, were preserved in $5 \%$ formol solution for one week and then weighed in the wet state. The width of the TMT (i.e. the minimum transversal distance between lateral and medial edges of TMT, dorsal view) was measured under the dissection microscope of 8 times magnifying power using an ocular micrometer. The size of MTS (i.e. the maximum distance between the dorsal and plantar edges of metatarsal spur cap transversally to the longitudinal axis of TMT) was measured using a larger magnification of the microscope (i.e. 20 times). Finally, all scales situated on the PDD III were counted. The obtained data were analyzed statistically and the significance of differences was assessed by means of Student's t-test. 
Table 1

Weight of foot, width of tarsometatarsus, size of metatarsal spur and number of scales of PDD III of the left (sin.) and right (dx.) foot in chicks

\begin{tabular}{|c|c|c|c|c|c|}
\hline \multirow[t]{2}{*}{ Character } & & \multicolumn{2}{|c|}{ Males $(n=31)$} & \multicolumn{2}{|c|}{ Females $(n=31)$} \\
\hline & & $\sin$. & dx. & $\sin$. & dx. \\
\hline $\begin{array}{l}\text { Mass } \\
\text { of foot } \\
\text { (mg) }\end{array}$ & $\begin{array}{l}\text { MEAN } \\
\text { SD } \\
\text { SE } \\
\text { CV (\%) }\end{array}$ & $\begin{array}{c}926 \mathrm{c} \\
75 \\
13 \\
8.1\end{array}$ & $\begin{array}{c}926 \mathrm{c} \\
68 \\
12 \\
7.4\end{array}$ & $\begin{array}{l}797 \mathrm{~d} \\
119 \\
21 \\
14.9\end{array}$ & $\begin{array}{l}803 \mathrm{~d} \\
122 \\
22 \\
15.1\end{array}$ \\
\hline $\begin{array}{l}\text { Width } \\
\text { of tarso- } \\
\text { metatarsus } \\
(\mu \mathrm{m})\end{array}$ & $\begin{array}{l}\text { MEAN } \\
\text { SD } \\
\text { SE } \\
\text { CV }(\%)\end{array}$ & $\begin{array}{c}3260 \mathrm{c} \\
117 \\
21 \\
3.6\end{array}$ & $\begin{array}{c}3324 \mathrm{c} \\
156 \\
28 \\
4.7\end{array}$ & $\begin{array}{c}3128 \mathrm{~d} \\
151 \\
27 \\
4.8\end{array}$ & $\begin{array}{c}3133 \mathrm{~d} \\
199 \\
36 \\
6.3\end{array}$ \\
\hline $\begin{array}{l}\text { Size } \\
\text { of metatarsal } \\
\text { spur } \\
(\mathrm{ym})\end{array}$ & $\begin{array}{l}\text { MEAN } \\
\text { SD } \\
\text { SE } \\
\text { CV (\%) }\end{array}$ & $\begin{array}{c}1429 \mathrm{a} \\
114 \\
20 \\
7.9\end{array}$ & $\begin{array}{c}1424 \mathrm{a} \\
138 \\
25 \\
9.7\end{array}$ & $\begin{array}{c}1343 \mathrm{~b} \\
154 \\
28 \\
11.5\end{array}$ & $\begin{array}{c}1347 \mathrm{~b} \\
140 \\
25 \\
10.4\end{array}$ \\
\hline $\begin{array}{l}\text { Number } \\
\text { of scales } \\
\text { of PDD III }\end{array}$ & $\begin{array}{l}\text { MEAN } \\
\text { SD } \\
\text { SE } \\
\text { CV (\%) }\end{array}$ & $\begin{array}{c}38.6 \mathrm{a} \\
7.2 \\
1.3 \\
18.6\end{array}$ & $\begin{array}{c}37.2 \mathrm{a} \\
7.4 \\
1.3 \\
19.8\end{array}$ & $\begin{array}{c}34.4 \mathrm{~b} \\
7.6 \\
1.4 \\
22.1\end{array}$ & $\begin{array}{c}33.3 \mathrm{~b} \\
7.9 \\
1.4 \\
23.9\end{array}$ \\
\hline
\end{tabular}

Means bearing different suffixes (ab) showed significant differences $(\mathrm{P}<0.05)$

Means bearing different suffixes (cd) showed significant differences $(\mathrm{P}<0.001)$

\section{Results}

As can be seen in Table 1, the mass of foot was one of the characters of sexual dimorphism in one-day-old chicks as it was higher by $15-16 \%$ in males than in females. This difference resulted also from a larger width of TMT which was wider by 4-6\% in males than in females.

In one-day-old chicks, the metatarsal spur (MTS) was practically identical in both sexes. This was a skin structure situated on the medial surface of the distal third of TMT, i.e. 3.5-4 mm proximally from the base of the 1st digit. Regarding its more plantar location, it was not superimposed on the bone of TMT but on tendons of digit flexors that were situated

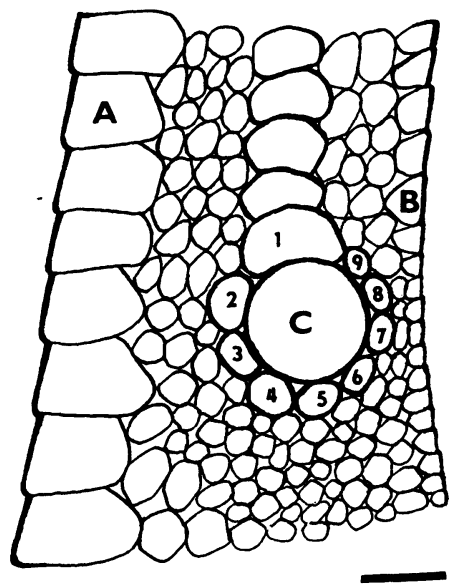

Fig. 1. The distal third of TMT of the right foot of a one-day-old chick as viewed from the medial side. A - scales of the dorsal region of TMT, B - scales of the plantar region of TMT, C - metatarsal spur, 1 to 9 - satellite scales situated around MTS. Scale bar $=1000 \mu \mathrm{m}$ on the plantar surface of TMT. A narrow strip of skin between the metatarsal spur and the base of the digit resembled a fine reticulation due to the presence of small rounded scales. MTS itself was developed as a semispherical skin swelling with a smooth surface. Its shape was mostly symmetric circular with a regular arching in the proximodistal and dorsoplantar direction. In not more than $15 \%$ of cases, MTS was slightly elongated in the proximodistal direction to resemble a symmetric oval with a smooth surface and of rounded shape. Special accessory scales were distributed around MTS as a crown, and formed a slightly elevated collar (Fig. 1). These satellite scales were of rounded, either oval or polygonal shape and their number was most frequently 8 to 9 , regardless of the size of MTS and the sex of bird. The numbers of seven and/or ten scales were exceptional are represented 3.2 and 8.1 $\%$ of all cases, respectively. Although the size 
of satellite scales was rather variable in dependence on their shape and number, the largest one being that situated proximally from the spur. As to its size, it reached as far as one half or three quarters of its size. The size of satellite scales situated more distally was gradually smaller in a ring that followed at first the dorsal, thereafter the distal and finally the plantar circumference of MTS.

When observing the cross section of TMT made in the middle of MTS it was possible to see that the spur was slightly strangulated at its base and that a narrow, circumferential groove was partially covered by the neighbouring elevated edges of satellite scales. It was also possible to measure the height of MTS (i.e. the distance between the plane of its base and the maximum peak of its convexity). This value ranged from 500 to $650 \mu \mathrm{m}$. The size of the spur itself was the only character that showed sexual differences within the whole complex of MTS (i.e. the MTS itself and the ring of satellite scales). In average, it was larger by $6 \%$ in males than in females.

The number of scales on PDD II showed to be a statistically significant character of sexual dimorphism as, in average, it was higher by $12 \%$ in males than in females.

\section{Discussion}

Our results indicated that higher mass of the foot, wider TMT and larger size of MTS represent secondary sexual characters in the males. They are markedly developed in adult individuals. However, these sexual differences begin to appear as soon as during the embryonal development and therefore they may be detected in newly hatched chicks. In this context it would also be interesting to find which organs or body parts are more developed in females, regarding that it has been generally accepted that the live body mass of hatched chicks does not differ between sexes. Besides the above-mentioned quantitative characters, the number of scales on PDD III was also related to the sex of the birds; this was demonstrated by $\mathrm{H}$ a $\mathrm{m} \mathrm{pl}$ (1992) in an earlier study using a different set of experimental material.

It seems that satellite scales form together with MTS itself a certain complex in one-day-old chicks preserving its juvenile traits also in adult females. In males, MTS becomes rather elongated, ossified and secondarily also grown together with the bone of TMT during the postincubation development. This fact may raise the question whether also the satellite scales are participating (and in what way) in the growth of MTS.

\section{Některé morfologické znaky sexuálního dimorfismu na noze kư̌at}

$\mathrm{S}$ cílem postihnout př́ípadné sexuální rozdíly $\mathrm{v}$ morfologickém utváření nohy jednodenních kư̌at bylo vyšetřeno 31 kohoutkủ a 31 kư̌iček. Bylo zjištěno, že kohoutci mají oproti kư̌ičkám statisticky průkazně $(P<0.001)$ těžśí nohy, a to o 15-16\%, sirší tarsometatarsy o 4$6 \%(\mathrm{P}<0.001)$, větší metatarsální ostruhy o $6 \%(\mathrm{P}<0.05)$ a vyšši počet supin $(\mathrm{P}<0.05)$ na distálním prstním polštári třetích prstů o $12 \%$.

\section{References}

BAUMEL J. J., KING A. S., LUCAS A. M., BREAZILE J. E., EVANS H.E. (eds.) 1979: Nomina Anatomica Avium. Academic Press, London

HAMPL A. 1992: The number of digital pad scales - a new sex character in the chick? Acta vet. Brno 61: 93-98 LUCAS A.M., STETTENHEIM P. R. 1972: Avian anatomy. Integument I, II. Washington, D.C., pp. 64-72, 595612

PUCHKOV V. F. 1970: Razvitiye shpor u zarodyschey cyplenka. Archiv anatomiyi, gistologiyi i embryologiyi 76: $32-41$ 